\title{
ANALISIS KUALITAS DAYA PADA SUPLAI DAYA LISTRIK PT. SOSRO
}

\author{
Aceng Daud \\ Jurusan Teknik Konversi Energi, Politeknik Negeri Bandung \\ Jl. Geger Kalong Hilir, Ciwaruga, Bandung \\ Email: daud polban@yahoo.com
}

\begin{abstract}
In more than ten years, quality of electricity has growed from clearness to be an principal issue. One heavy problems from quality of power is harmonic distortion and its consequences. Particularly, the increasing of penetration of loads bases on power electronics (nonlinear load) what creates a harmonic distortion in AC power systems. Then, quality of electricity becomes principal issue for utility and its consumer and both swiftly adopts philosophy and proposes limits in new international standard (IEC, EN, BS, IEEE). As consequence the equipments of power conditioning (converter) will become more important for electrical utility and its consumer. From the results with the data logger recording at PT.SOSRO distribution feeder system found that there are several current and voltage harmonics are significant in the load and hence the supply side. Fifth and the seventh Harmonic are heaviest harmonic components in the current load. Installation of passive filters will be one solution to overcome the issue with the current harmonics. The recomendation proposed will be submitted to management for consideration PT.SOSRO factory in determining which type of passive filter will be used.
\end{abstract}

Keywords: power quality, harmonic, filter, variable speed drive.

\section{PENDAHULUAN}

PT. Sosro adalah salah satu perusahaan pembuat minuman yang berlokasi di Padeglang Banten. Perusahaan tersebut pada saat ini sedang menghadapi masalah yang cukup berat, yaitu meledaknya bangku kapasitor koreksi faktor daya. Kemudian, beberapa minggu setelah dilakukan penggantian terjadi ledakan lagi. Dengan kejadian tersebut mengakibatkan penambahan biaya untuk mengganti bangku kapasitor sistem distibusi tersebut.

Beban total pabrik tersebut adalah sekitar 1000 $\mathrm{kW}$ dengan beban puncak sekitar $1600 \mathrm{~kW}$. Sekitar 50\% dari beban puncak yaitu Variable Speed Drives (VSD), yang variasi frekuensi suplainya antara $50 \sim 1 \mathrm{kHz}$.

Berdasarkan hal tersebut, pihak manajemen ingin melakukan suatu pemantauan sistem untuk menemukan sejumlah harmonik yang signifikan dalam arus dan tegangan beban. Sasaran pemantauan adalah melakukan suatu pemantauan sistim yang lengkap dan menemukan penyebab meledaknya kapasitor, terjadinya harmonik dan mengusulkan solusisolusi yang mungkin dilakukan.

Kecepatan yang dapat diatur (adjustable) dan penggerak (drive) dc, bersama dengan power supplai switch-mode, menyebabkan arus harmonik karena karakteristik takliniernya. Arus harmonik ini dapat bergabung dengan karakteristik respons frekuensi sistem yang menyebabkan distorsi tegangan harmonik. Distorsi ini dapat menyebabkan kerusakan kendali, kegagalan kapasitor, motor dan transformer terlalu panas, dan peningkatan kerugian sistem. Masalah ini diperparah dengan penggunaan bangku kapasitor yang dapat menyebabkan pembesaran kondisi resonansi dan tingkat distorsi harmonik. Bangku-bangku kapasitor ini biasanya dipasang untuk keperluan koreksi faktor daya, serta untuk meningkatkan kapasitas transformator. IEEE Std 519 menetapkan batas ketat distorsi arus (Lihat Tabel 1).

Harmonik diciptakan oleh beban-beban tidak linier yang menarik arus dalam pulsa-pulsa kasar dibanding dalam suatu cara sinusoida yang halus. Tegangan dan arus sistim daya bersifat gelombang sinusoida (Gambar 1a). Harmonik adalah komponen sinusoida, suatu gelombang periodik yang merupakan kelipatan integral dari frekuensi fundamental. Superposisi harmonik dengan fundamental 
akan mendistorsi bentuk gelombang yang asli (Gambar 1b).

Tabel 1: Batas distorsi arus dan tegangan berdasarkan standar IEEE Std-519

\begin{tabular}{|c|c|c|c|c|c|c|}
\hline \multicolumn{7}{|c|}{ Distorsi Arus } \\
\hline \multicolumn{7}{|c|}{$\begin{array}{c}\text { MAXIMIM HARMONIC CURRENTDISTORSION IN } \\
\% \text { OF FUNDAMENTAL }\end{array}$} \\
\hline \multirow[t]{2}{*}{$\mathrm{I}_{\mathrm{SC}} / \mathrm{I}_{\mathrm{L}}$} & \multicolumn{5}{|c|}{ Harmonic Order (OddnHarmonic) } & \multirow{2}{*}{$\begin{array}{l}\text { THD } \\
(\%)\end{array}$} \\
\hline & $<11$ & $\begin{array}{l}11=h \\
=17\end{array}$ & $\begin{array}{c}17=h \\
=23\end{array}$ & & $\begin{array}{l}35 \\
=\mathbf{h}\end{array}$ & \\
\hline$<20$ & 4.0 & 2.0 & 1,5 & & 0,3 & 5.0 \\
\hline $20-50$ & 7,0 & 3,5 & 2,5 & & 0.5 & 8,0 \\
\hline $\begin{array}{l}50- \\
100\end{array}$ & 10.0 & 4.5 & 4,0 & & 0,7 & 12.0 \\
\hline $\begin{array}{l}100- \\
1000\end{array}$ & 12.0 & 5.5 & 5,0 & & 1,0 & 15.0 \\
\hline$>1000$ & 15.0 & 7,0 & 6,0 & & 1.4 & 20,0 \\
\hline \multicolumn{7}{|c|}{ Distorsi Tegangan } \\
\hline \multicolumn{2}{|c|}{$\begin{array}{l}\text { Voltage at } \\
\text { PCC }\end{array}$} & \multicolumn{3}{|c|}{$\begin{array}{c}\text { Individual } \\
\text { Component } \\
\text { Voltage Distorsion }\end{array}$} & \multicolumn{2}{|c|}{$\begin{array}{l}\text { Total Voltage } \\
\text { Distorsion } \\
\left(\mathrm{THD} V_{\mathrm{F}}\right)\end{array}$} \\
\hline \multicolumn{2}{|c|}{$\mathrm{V}<69 \mathrm{kV}$} & \multicolumn{3}{|c|}{$3,00 \%$} & \multicolumn{2}{|c|}{$5,00 \%$} \\
\hline \multicolumn{2}{|c|}{$\begin{array}{c}69 \mathrm{kV}<\mathrm{V} \\
161 \mathrm{kV}\end{array}$} & \multicolumn{3}{|c|}{$1.5 \%$} & \multicolumn{2}{|c|}{$2,5 \%$} \\
\hline \multicolumn{2}{|c|}{$V=161 \mathrm{~kJ}$} & \multicolumn{3}{|c|}{$1,00 \%$} & \multicolumn{2}{|c|}{$1.5 \%$} \\
\hline
\end{tabular}

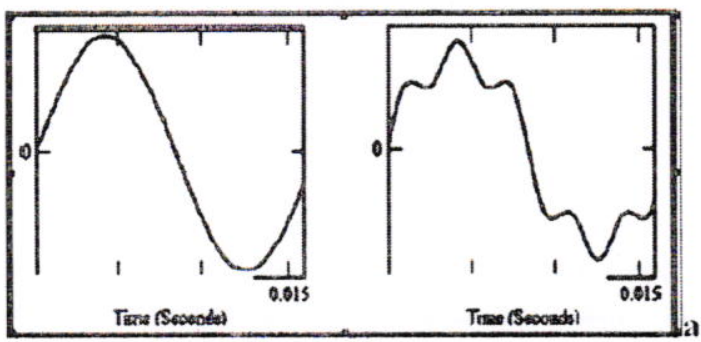

b

Gambar 1: Bentuk gelombang fundamental dan berisi harmonik: (a) Bentuk gelombang funda-mental $50 \mathrm{~Hz}$ normal; (b) Bentuk gelombang berisi fundamental plus harmonik ke ketiga dan lima.

Tingkat kecacatan gelombang tegangan dan arus dinyatakan dengan Total Harmonic distorsion (THD). Untuk distorsi harmonik arus dinyatakan sebagai berikut:

$$
\mathrm{THD}_{i}=\frac{\sqrt{I_{r m s}^{2}-I_{1}}}{I_{I}} \times 100 \%
$$

\section{METODAPENELITIAN}

Pada penelitian kualitas daya listrik sistim distribusi di PT.SOSRO, data direkam dengan menggunakan"Data Logger" dan "Network Analyser".
Ada lima penyulang (feeder) yang keluar dari bus bar utama, yang terdiri atas beberapa variable speed drive (VSD). Data logger dihubungkan pada beban dari masing-masing penyulang. Network Analyser dihubungkan pada bus bar utama seperti ditunjukan dalam Gambar 2. Data dicatat, dibukukan dengan Data Loggers dan Network Analyser.

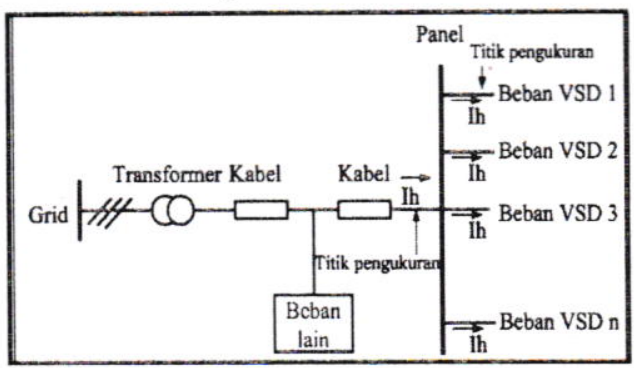

Gambar 2: Diagram satu garis sistem distribusi listrik di PT.SOSRO

\section{HASIL DAN PEMBAHASAN}

Gambar 3 sampai 6 merupakan contoh profil tegangan $\&$ arus dari titik-titik pengukuran data yang dirckim.

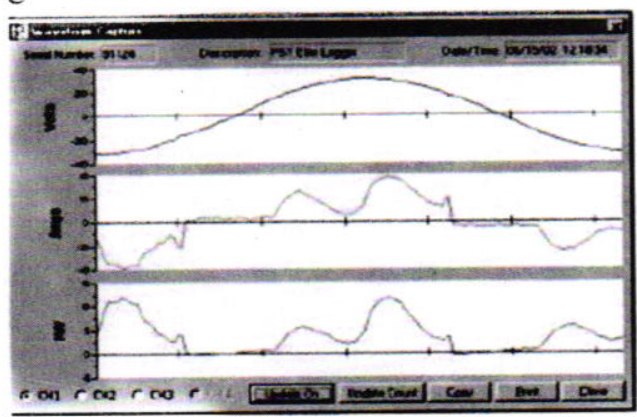

Gambar 3: Bcntuk gelombang tegangan \& arus yang diperoleh dari penyulang yang dihubungkan pada beban VSD

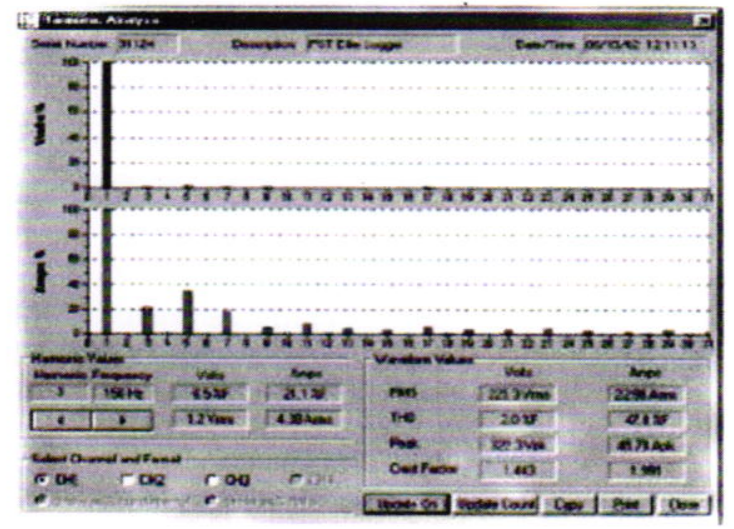

Gambar 4: Spektrum harmonik tegangan \& Arus yang diperoleh dari penyulang yang dihubungkan pada beban VSD 
Data Tegangan/Arus fase:

- Tegangan rms : 223,3V

- Arus rms : 22,99A

- THD tegangan : $2,0 \%$

- THD arus : $47,8 \%$

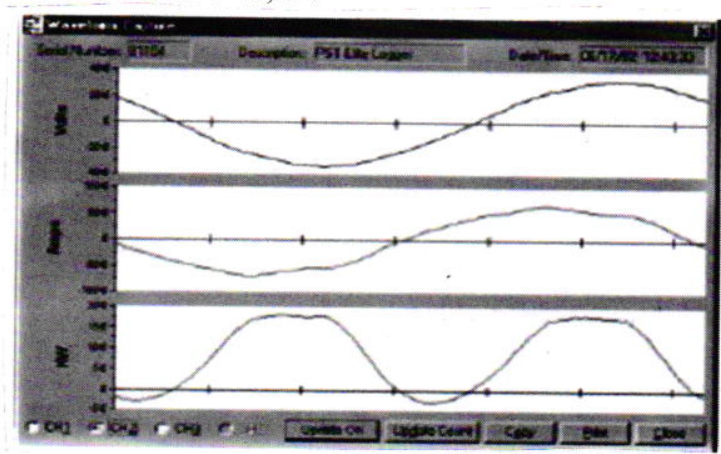

Gambar 5: Bentuk gelombang Tegangan \& Arus yang diperoleh dari busbar utama

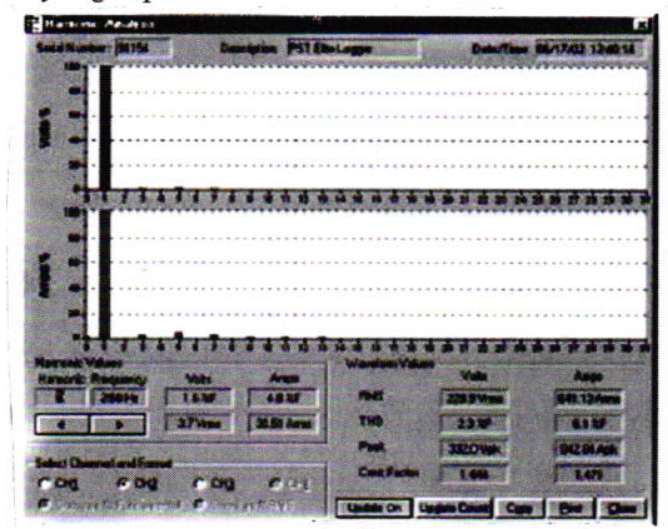

Gambar 6: Spektrum Tegangan \& Arus yang diperoleh dari busbar utama

Data Tegangan/Arus fase

- Tegangan rms : 229,9V

- Arus rms: 641,13A

- THD tegangan : $2,3 \%$

- THD arus : $6,1 \%$

Dari hasil analisis data yang direkam, ditemukan bahwa beban penyulang VSD-3 berisi sejumlah harmonik arus yang signifikan, yaitu 6,3\% dan sudah diluar batas standar yang diijinkan yaitu $5 \%$.

Sebagai contoh jika harmonik kelima dari bentuk gelombang arus dipertimbangkan;

- arus rms fundamental : 20,79 A

- rms dari harmonik ke lima: 7,07 A

- $\quad$ sebagai $\%$ dari fundamental : $34,15 \%$

Jika bus bar utama dipertimbangkan, harmonik kelima dari bentuk gelombang arus: .
- arus rms fundamental : 635,63 A

- rms dari harmonik ke lima:30,51A

- sebagai $\%$ dari fundamental : $4,80 \%$

Bangku kapasitor yang diperuntukan koreksi faktor daya akan mengintrodus suatu resonansi antara harmonik ke tujuh dan ke lima yang menguatkan ke dua komponen ini.

Ada beberapa metode dasar yang dapat digunakan untuk mengurangi distorsi harmonik, antara lain:

- Meningkatkan impedansi sumber efektif,

- Pengalihan harmonik ke jalur alternatif,

- Menggunakan metode hybrid yang menggabungkan kedua item di atas, dan

- Pembatalan harmonik.

\section{Meningkatkan impedansi sumber efektif}

Kita dapat memprediksi distorsi arus harmonik untuk penyearah 6-pulsa yang didasarkan atas sumber impedansi efektif, atau jatuh tegangan sumber daya pada operasi arus beban. Sehingga kita dapat meningkatkan sumber impedansi efektif dengan menambahkan reaktor saluran atau transformator isolasi.

Pada sistem listrik secara umum, trafo pasokan adalah sumber impedansi utama. Impedansi papan nama trafo didasarkan pada kondisi operasi beban penuh. Cara mudah untuk mengevaluasi impedansi sumber efektif relatif terhadap beban individu, adalah dengan menggunakan persamaan berikut:

$\% Z_{\text {eff }}=\% Z_{\text {n.p }} \cdot \mathrm{KVA}_{\text {Load }} / \mathrm{KVA}_{\mathrm{Xfnr}}$

Dalam banyak kasus, kapasitas daya transformator jauh lebih besar dari kapasitas beban individu, sehingga impedansi efektif jauh lebih rendah dari yang ditunjukkan pada papan nama trafo. Persen distorsi arus harmonik (THDI) biasanya lebih tinggi untuk beban kecil dibandingkan beban besar, karena impedansi efektiflebih rendah.

Oleh karena itu, kita dapat mengurangi distorsi arus harmonik dengan meningkatkan impedansi sumber efektif relatif terhadap beban individu. Salah satu cara yang sering dilakukan adalah dengan menambahkan reaktor-saluran terhubung seri pada masukan ke berbagai beban 
dengan menggunakan penyearah 6-pulsa, seperti VFD. Jumlah tipikal dari impedansi reaktorsaluran berkisar antara $2 \%$ sampai $5 \%$.

Arus harmonik sering kali diperlakukan sebagai suatu masalah lokal pada jaringan distribusi. Impedansi dari jaringan distribusi akan mengurangi perambatan harmonik. Oleh karena itu, untuk mitigasi harmonik dilakukan dengan menempatkan filter harmonik pasif yang dipasang dekat sumber arus harmonik. Sehingga peralatan lain tidak akan dipengaruhi oleh harmonik yang dihasilkan beban.

\section{Pengalihan frekuensi harmonik tertentu dari sumber daya}

Teknik ini menggabungkan reaktor dan kapasitor untuk membentuk rangkaian yang mengakibatkan impedansi rendah untuk frekuensi harmonik dari sumber listrik. Di sini, filter detune terhubung secara paralel dengan sumber listrik untuk mengalihkan harmonik ke filter, dan mencegah sebagian arus harmonik mengalir ke sumber listrik. Arus harmonik yang besar akan mengalir pada beban linier dan filter, sedangkan arus harmonik yang lebih rendah akan mengalir ke sumber listrik.

Jenis filter ini cocok untuk digunakan dengan satu atau beberapa beban, termasuk kombinasi kedua beban linier dan taklinier. Desain filter didasarkan pada besar harmonik yang akan disaring, frekuensi harmonik yang hendak dihapus dan impedansi dari sumber listrik. Di samping itu, pertimbangan desain harus menjamin sambungan dari filter harmonik tidak menyebabkan kondisi resonansi pada sistem tenaga listrik yang dapat menguatkan frekuensi harmonik.

Kita dapat memasang filter detune pada beban individu (Gambar 7) atau pada lokasi pusat untuk pemilteran fasilitas bulk (Gambar 8). Jika 'kita menerapkan filter massal pada switchboard utama atau transformator, harmonik akan terus mengalir pada fasilitas (internal) sistem daya antara titik sambungan filter dan beban hilir.

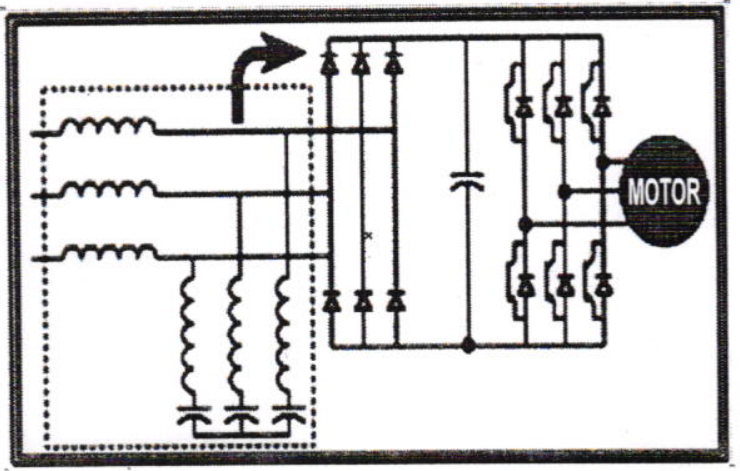

Gambar 7: Filter detune, untuk beban-beban individu. Panah menunjukan aliran arus harmonik

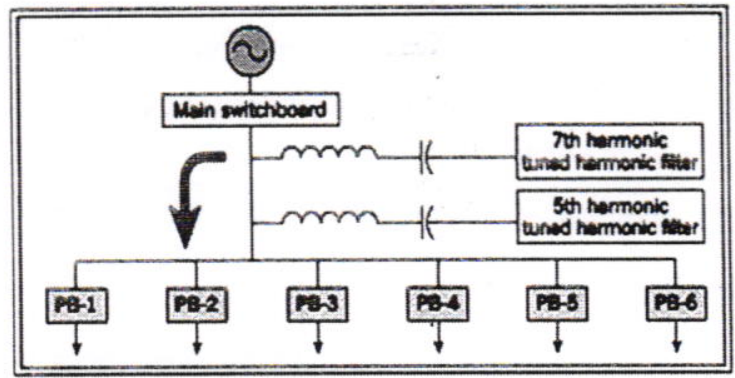

Gambar 8: Filter detune untuk pemilteran bulk. Panah menunjukan aliran arus harmonik

Jika kita menerapkan filter pada beban individu, maka harus menerapkan reaktor terhubung seri pada masukan ke filter. Hal ini akan mencegah jaringan disetel (detune) dari penarikan harmonik beban lain menjadi kelebihan beban. Reaktor ini pada dasarnya merupakan filter detune terhadap hulu terhubung beban.

Suatu filter shunt pasif tipikal dan menghasilkan impedansi ekivalen dilihat dari beban ditunjukkan pada Gambar 9. Filter pasif berisi sederet filter LC yang disetel untuk harmonik yang spesifik dalam kombinasi dengan suatu filter high pass yang umum digunakan untuk menghapus arus harmonik orde yang lebih tinggi.

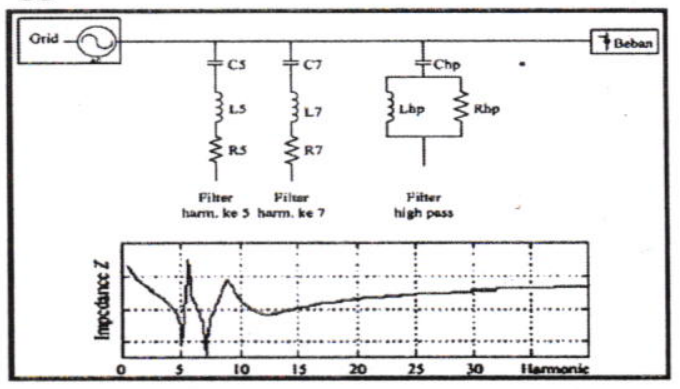

Gambar 9: Filter harmonik pasif tipikal untuk impedansi ekivalen dan pengurangan harmonik arus 
Sebelum memasang filter pasif, besarnya daya reaktif pada sistem harus diketahui. Daya reaktif sistem ini diperlukan untuk menghitung besarnya nilai kapasitor yang diperlukan untuk memperbaiki sistem.

Beșarnya nilai kapasitif pada filter pasif dapat dihitung sbb:

$$
C_{n}=\frac{Q_{n}}{V_{L N}^{2}}
$$

Nilai induktif dari filter dapat dihitung sbb?

$$
L_{n}=\frac{1}{(2 x \pi x f)^{2} x C_{n}}
$$

Menggunakan filter hibrida untuk mengurangi dan mengalihkan harmonik

Salah satu filter harmonik paling efektif untuk satu atau beberapa beban taklinier adalah filter harmonik low pass, seperti yang ditunjukkan Gambar 10. Filter hibrida ini menggabungkan filter detune dengan tambahan reaktor saluran, yang dirancang untuk mencapai tingkat distorsi harmonik arus kurang dari 5\% THDI. Ketika ketiga tahap ini dilakukan, maka dapat mencegah daya tarik harmonik dari beban lain, juga dapat mencegah resonansi harmonik terhadap ke dua sirkuit masukan dan keluaran.

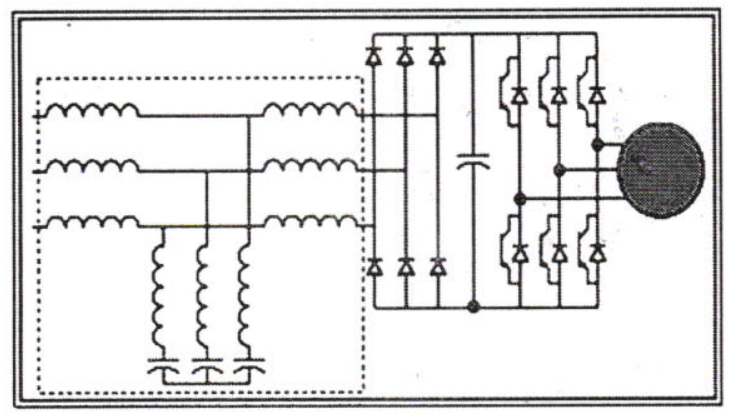

Gambar 10: VFD dengan filter harmonik low pass, diperlihatkan dengan garis putus-putus

Tiga tahap filter digabungkan dalam jenis filter ini untuk membatasi distorsi harmonik (VFD) pada kisaran 3\% sampai 5\%. Distorsi harmonik mungkin lebih tinggi untuk drive $D C$ dan skema konversi daya serupa dengan menggunakan SCR fase-terkendali. Impedansi seri (masukan ditambah keluaran) mengurangi besarnya arus harmonik yang dihasilkan oleh penyearah 6pulsa dari beban VFD. Rangkaian shunt disetel untuk menghapus sebagian besar harmonik ke-5, biasanya yang paling dominan dalam aplikasi penyearah 3-fase, 6-pulsa.

Ketika semua dari tiga tahap digunakan, filter low pass memiliki kemampuan untuk mencapai tingkat distorsi harmonik sekitar 5\% THDI saat beroperasi pada beban $0 \%-100 \%$.

Metoda ini berisi sederet bangku kapasitor yang dapat disetel pada harmonik yang paling rendah, yaitu kelima. Hal ini dilaksanakan dengan memasukan suatu induktor secara seri dengan kapasitor, seperti yang ditunjukkan pada Gambar 11.

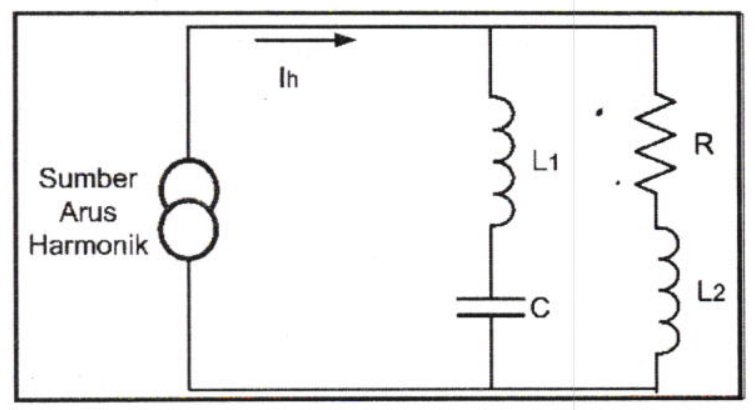

Gambar 11: Rangkaian ekivalen per fase sistim dengan induktor detuning

Begitu induktor detuning diinstall di sana akan ada dua frekwensi resonansi.

$$
f_{s}=\frac{1}{2 \pi \sqrt{L_{l} C}} ; f_{p}=\frac{1}{2 \pi \sqrt{\left(L_{l}+L_{2}\right) C}}
$$

dimana:

$\mathrm{f}_{p}=$ frekuensi parallel tuning

$\mathrm{f}_{s}=$ frekuensi seri tuning

\section{Pembatalan Harmonik}

Ada dua metode dasar untuk mencapai pembatalan harmonik arus, yaitu teknologi pasif menggunakan gulungan transformator pergeseran fase dan filter aktif menggunakan teknologi transistor IGBT.

Metode penyearahan 12 dan 18-pulsa telah digunakan selama bertahun-tahun, terutama pada aplikasi motor. Suatu konverter 12-pulsa menggunakan dua penyearah jembatan 6-pulsa yang dipasok dari dua sumber daya yang berbeda. Fase listrik sumber daya ini bergeser 30 derajat, mengakibatkan pembatalan harmonik ke-5 dan ke-7. Demikian pula, konverter 18pulsa menggunakan tiga set penyearah jembatan 6-pulsa yang dipasok dari tiga sumber daya yang 
berbeda, masing-masing fasa yang digeser sebesar $20^{\circ}$ derajat. Susunan ini menyebabkan pembatalan harmonik ke 5, 7, 11, dan 13. Keuntungan dari jenis konverter ini adalah daya harmonik yang dihasilkan lebih sedikit dibandingkan dengan metode penyearahan 6pulsa standar. Kita dapat menentukan harmonik yang dihasilkan oleh setiap metode penyearahan dengan menggunakan persamaan ini.

$\mathrm{h}=(\mathrm{k} \cdot \mathrm{p}) \pm 1$

di mana: $\mathrm{h}=$ jumlah harmonik, $\mathrm{k}=$ konstanta $(1,2,3$ dst), $\mathrm{p}=$ jumlah pulsa.

Oleh karena itu, konverter 12-pulsa, yang memiliki 12 dioda, menciptakan tegangan bus DC 12 pulsa dari per siklus tegangan masukan AC, akan menghasilkan jumlah harmonik 11, 13, 23, 25, 35, 37, dll. Konverter 18-pulse (Lihat Gambar 12) hanya akan menghasilkan jumlah harmonic 17, 19, 35, 37, dll. Bandingkan dengan konverter 6-pulsa standar, yang menghasilkan harmonik $5,7,11,13,17,19,23,25$, dll. Menggunakan konverter 18-pulsa biasanya akan mengurangi harmonik sekitar 5\% THDI pada kondisi beban penuh. Sebuah konverter 12-pulsa biasanya mencapai sekitar $10 \%-12 \%$ THDI pada beban penuh.

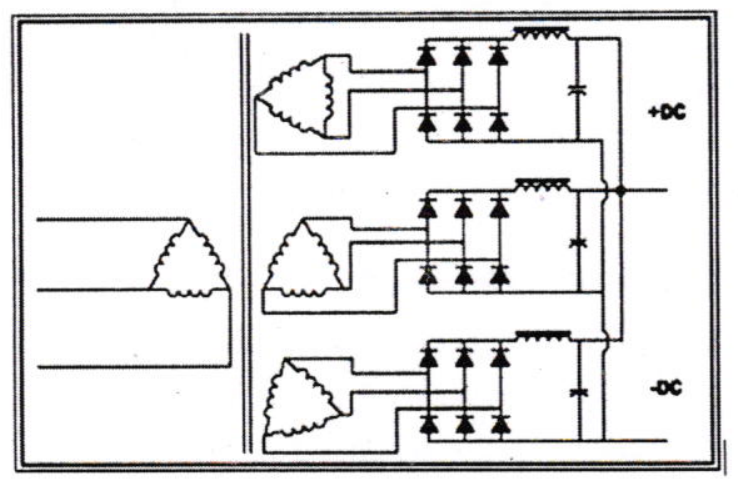

Gambar 12: Konfigurasi penyearah jembatan 18pulsa terhubung paralel.

Metoda multi-pulse melibatkan konverter ganda sehingga harmonik yang dihasilkan oleh satu konverter diganti oleh harmonik dari konverter lain. Konverter pulsa ganda memberikan suatu teknik yang efektif dan sederhana untuk mengurangi harmonik dari konverter elektronik daya. Metoda multi-pulse identik dengan penggunaan konverter-konverter ganda atau peranti-peranti semikonduktor ganda, dengan suatu beban.
Transformator pergeseran fase cukup penting dan terdapat mekanisme untuk pembatalan pasangan harmonik arus, seperti harmonik kelima dan ketujuh, atau kesebelas dan ketigabelas dan yang lainnya.

Simulasi pada penyulang VSD 3 seperti yang diperlihatkan pada Gambar 2 di atas dilakukan dengan menggunakan MATLAB Simulink dengan parameter-parameter sebagai berikut:

Tegangan tarfo $=400 / 220, Z=4 \%, f=50 \mathrm{~Hz}$, $\mathrm{X} / \mathrm{R}=3,18, \mathrm{R}$ sumber $=0,00767 \mathrm{ohm}, \mathrm{L}$ sumber $=7,67 \mathrm{e}-5$ henry. Beban non linier sebesar 3917, 22 watt per fase dengan $\mathrm{R}$ beban sebesar 2,109 ohm dan L beban sebesar 0,058 henry. Dari hasil pengujian ditemukan bahwa daya reaktif beban sebesar 3287 Var.

Perbandingan persentase harmonisa arus yang dominan (ketiga, kelima dan ketujuh) adalah $21 \%, 38 \%$ dan $19 \%$, sehingga daya reaktif untuk masing-masing filter harmonisa adalah:

$\mathrm{Q}_{1}=0,21 \times 3287=690,3 \mathrm{Var}$

$\mathrm{Q}_{2}=0,38 \times 3287=986 \mathrm{Var}$

$\mathrm{Q}_{3}=0,19 \times 3287=624,5 \mathrm{Var}$

Filter yang digunakan adalah jenis single tune, ketiga filter pasif ini dihubungkan ke penyulang seperti pada Gambar 13.

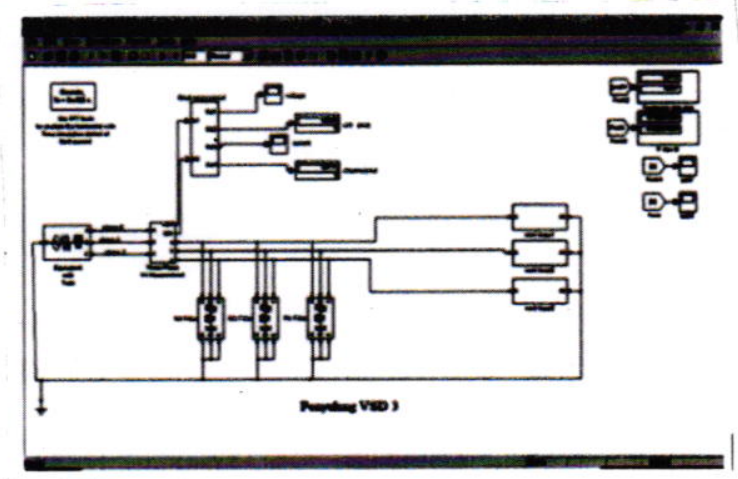

Gambar 13: Pemasangan filter pasif pada penyulang VSD 3.

Nilai R, L dan C untuk masing-masing filter pasif tersebut diperlihatkan pada Tabel 2.

Tabel 2. Nilai $\mathrm{R}, \mathrm{L}$ dan $\mathrm{C}$ untuk tiap jenis filter

\begin{tabular}{|l|c|c|c|}
\hline \multirow{2}{*}{ Jenis Filter } & \multicolumn{3}{|c|}{ Parameter Filter } \\
\cline { 2 - 4 } & $\mathrm{R}(\mathrm{Ohm})$ & $\mathrm{L}(\mathrm{H})$ & $\mathrm{C}(\mathrm{F})$ \\
\hline $\mathrm{F} 3 / 150 \mathrm{~Hz}$ & 0,000001 & 0,0054 & 0,000209 \\
\hline $\mathrm{F} 5 / 250 \mathrm{~Hz}$ & 0,000001 & 0,00448 & 0,000091 \\
\hline $\mathrm{F} 7 / 350 \mathrm{~Hz}$ & 0,000001 & 0,00404 & 0,000051 \\
\hline
\end{tabular}


Hasil dari penambahan filter-filter pasif ini diperoleh THD arus yang diperlihatkan pada Gambar 14 dan spektrum harmonisa yang ditunjukan pada ( Gambar 15

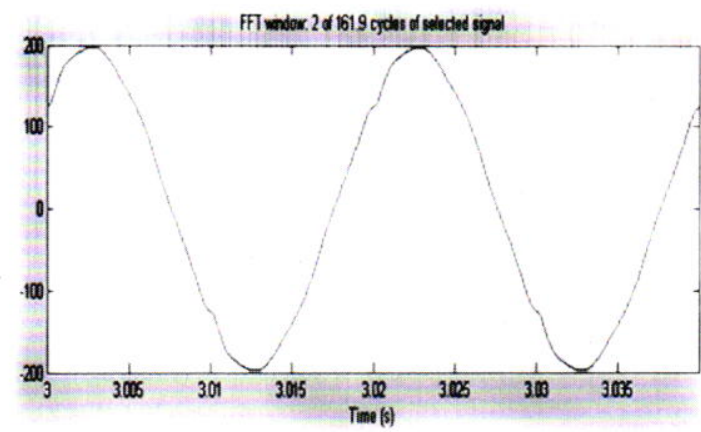

Gambar 14. THD arus pada VSD 3 setelah penambahan tilter past

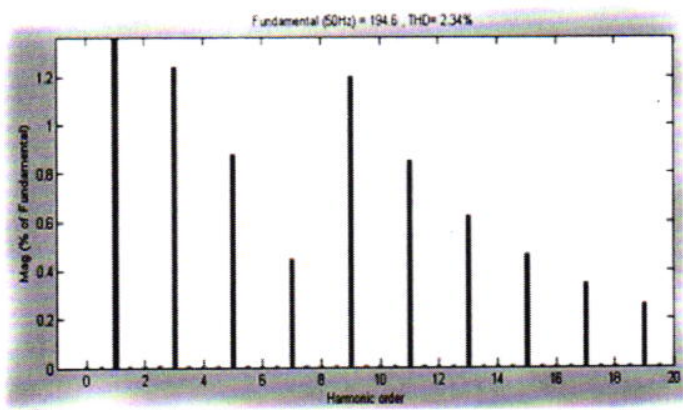

Gambar 15: Spektrum arus pada VSD 3 setelah penambahan filter pasif

Pada Gambar 14 terlihat bahwa bentuk arus sudah sangat mendekati sinusioda dibandingkan sebelum pakai filter (Gambar 3). Nilai THD arus untuk harmonisa ke tiga, lima dan tujuh setelah pemakaian filter adalah $1,2 \% ; 0,9 \%$ dan $0,42 \%$. Ini sudah sangat menurun dibandingkan sebelum pemasangan filter pasif yaitu $21 \%, 38 \%$ dan $19 \%$.

\section{KESIMPULAN}

Dengan menganalisa data logger sistim distribusi PT.SOSRO ditemukan sejumlah harmonik arus yang signifikan dalam sisi beban dan sisi suplai. Harmonik kelima dan ketujuh adalah komponen-komponen harmonik paling berat dalam arus beban.

Pemilihan yang tepat dari filter pasif dan aktif dapat menyebabkan kesalahpahaman karena sejumlah parameter beban tak-linier dan impedansi saluran tidak diketahui. Tetapi memilih ukuran filter yang benar adalah kunci untuk mencapai biaya optimal, yaitu pengurangan dalam harmonik arus dengan sedikit usaha pemfilteran. Mengingat bahwa beberapa peripheral penggerak motor seperti filter EMI, reaktor-saluran atau filter keluaran dirancang dan dipilih berdasarkan arus saluran, maka sering kali asumsi bahwa hal ini juga sesuai untuk filter harmonik adalah salah. Prosedur yang benar adalah dengan memilih filter harmonik pasif berdasarkan harmonik yang akan dihapuskan, yaitu harmomik ke tiga, ke lima dan ke tujuh. Impedansi jaringan $Z_{1}$ termasuk impedansi transformer $\mathrm{Z}$, tegangan $\mathrm{V}$, frekuensi $F$, daya nyata beban $P$, dan daya reaktif Q harus diketahui.

\section{DAFTAR PUSTAKA}

1. Arrillaga, Jos. 2000. Power System Harmonic Analysis. New Zealand: University of Canterbury.

2. DerekA., Paice. Power Electronic Converter Harmonics.

3. Duffey, C. K, 1989. Update of Harmonic Standard IEEE-51. IEEE Transaction on Industry Application, Vol.25. No.6, November 1989.

4. Dugan ; McGranaghan ; Santoso ; Beaty . 2003. Electrical Power System Quality Second Edition. USA : McGraw-Hill.

5. Grady, M. 2006. Understanding Power System Harmonics. USA : Departement Electrical \& Computer Engineering University of Texas at Austin.

6. IEEE Recommended Practices and Requirements for Harmonic Control in Electric Power Systems, IEEE Std 519-1992

7. John Houdek, Mitigating Harmonics in Industrial Environment.

8. Sarath Perera . Lecturer at the University of Wollongong, Austrailia.

9. Tanoto, 2005. Simulasi Filter Pasif dan Perbandingan Unjuk Kerjanya dengan Filter Aktif dan Filter Aktif Hibrid dalam Meredam Harmonisa pada Induction Furnace. Surabaya: Universitas Kristen Petra.

10. Wilson E.Kazibwe \& Musoke H. Sendaula, Electric Power Quality Control Technique.

11. Electrotek Concepts, Inc.Knoxville, TN, www.electrotek.com 